Research Article

\title{
KAHRAMANMARAŞ İLİ DULKADİROĞLU BÖLGESİ KATI ATIK BİLEŞENLERİNİN ARAŞTIRILMASI
}

\author{
Halil GÖKPUR ${ }^{1}$, Cengiz Ayhan ZIBA², Mustafa DOLAZ ${ }^{* 1}$ \\ ${ }^{1}$ Kahramanmaraş Sütçü İmam Üniversitesi, Mühendislik ve Mimarlık Fakültesi, Çevre Mühendisliği Bölümü, \\ Türkiye \\ ${ }^{2}$ Kahramanmaraş Sütçü İmam Üniversitesi, Göksun Meslek Yüksekokulu, Kahramanmaraş, Türkiye
}

\begin{tabular}{|c|c|}
\hline Anahtar Kelimeler & Öz \\
\hline $\begin{array}{l}\text { Katı atık, } \\
\text { Geri dönüşüm, } \\
\text { Dulkadiroğlu Belediyesi, } \\
\text { Kahramanmaraş. }\end{array}$ & $\begin{array}{l}\text { Ülke ekonomisinin gelişmesiyle birlikte kentleşme ve nüfus artışı da hızlanmakta } \\
\text { ve buna bağlı olarak çevresel atıklarda da büyük oranda artış görülmektedir. } \\
\text { Oluşan bu atıkların gömülerek veya yakılarak bertaraf edilmesi yerine geri } \\
\text { kazanılması için yeni teknolojilerin geliştirilmesi gerekmektedir. Geri } \\
\text { kazanılabilecek atıklardan endüstride kullanılabilecek hammadde elde edilmesi, } \\
\text { hem endüstrinin hammadde ihtiyacını hem de dışa bağımlılığı azaltarak } \\
\text { ekonomiye katkı sağlanmış olacaktır. Bu çalışmada } 2017 \text { yll Nisan-Mayıs } \\
\text { aylarında Kahramanmaraş ili Dulkadiroğlu ilçesi sınırları içerisindeki konutlarda } \\
\text { oluşan evsel katı atıklar, "Kent Merkezi", "Düşük Gelir Seviyesi", "Orta Gelir } \\
\text { Seviyesi" ve "Yüksek Gelir Seviyesi" olmak üzere, dört bölgeye ayrılarak ele } \\
\text { alınmış ve irdelenmiştir. Bu bölgelerden toplanan katı atık bileşenlerinde en } \\
\text { yüksek oranı \% } 55,90 \text { ile mutfak atıklarının, sonra sırasıla \% } 12,50 \text { ile plastik } \\
\text { atıkların, \% 9,80 ile diğer yanabilen atıkların ve \% } 8 \text { ile kâğı̆t atıklarının } \\
\text { olușturduğu görülmüștür. }\end{array}$ \\
\hline
\end{tabular}

\section{INVESTIGATION OF SOLID WASTE COMPONENTS IN DULKADIROGLU REGION, KAHRAMANMARAS PROVINCE}

Keywords
Solid waste,
Recycling,
Dulkadiroglu Municipality,
Kahramanmaraş Province.

Alıntı / Cite

Gökpur, H., Zıba, C. A., Dolaz, M., (2019). Kahramanmaraş İli Dulkadiroğlu Bölgesi Katı Atık Bileşenlerinin Araştırılması, Mühendislik Bilimleri ve Tasarım Dergisi, 7(2), 345-351.

Yazar Kimliği / Author ID (ORCID Number)

H. Gökpur, 0000-0003-2886-5762

C. A. Zıba, 0000-0003-2372-6819

M. Dolaz, 0000-0002-9684-5555

\begin{abstract}
The development of the country's economy increases urbanization and population. Depending on the increase in population, environmental wastes are increasing. New technologies need to be developed to recover these wastes instead of being buried or burned. It will be ensured that the raw material that can be used in the industry from the wastes recovered will contribute to the economy by reducing both the raw material needs of the industry and the dependence on foreign sources. In this study, domestic solid wastes generated in residential areas within the boundaries of Dulkadiroğlu district of Kahramanmaraş province in April-May 2017 were discussed and divided into four regions as City Center, Low Income Level, Middle Income Level and High Income Level. In the solid waste components collected from these regions, the highest rate was found to be 55,90\%, which was followed by kitchen waste, $12,50 \%$ by plastic wastes, $9,80 \%$ by other flammable wastes and $8 \%$ by paper wastes.
\end{abstract}

\section{MakaleSüreci / Article Process}

BaşvuruTarihi / Submission Date

RevizyonTarihi / Revision Date

Kabul Tarihi / Accepted Date

Yayım Tarihi / Published Date
05.11 .2018

25.12.2018

20.01.2019

26.06.2019

\footnotetext{
* ilgili yazar / Corresponding author: mdolaz@ksu.edu.tr, +90-344-300-1683
} 


\section{Giriş}

"Atık" sözlük anlamı itibariyle değeri düşük, kullanılmayan veya faydasız kalıntı olarak ifade edilmektedir. Birleşmiş Milletler Çevre Programına (UNEP) göre ise atık "sahibinin istemediği, ihtiyacı olmadığı, kullanmadığı, arıtılması ve uzaklaștırılması gereken maddeler" olarak tanımlanmaktadır (Öztürk, 2011).

Hammaddeden başlayarak işlenmiş ürün elde edilene kadar, bir ürünün üreticiden kullanıcıya veya tüketiciye ulaştırılması için taşınması, korunması, saklanması ve satışa sunulması amacıyla kullanılan, herhangi bir malzemeden yapılmıș ürünlere ise ambalaj denilmektedir (T.C. Resmi Gazete, 2015). Üretim aşamasında meydana gelen artıkları dışında, ürünlerin veya herhangi bir malzemenin tüketiciye ya da nihai kullanıcıya ulaştırılmasında kullanılan ambalajların, ürün sunumundan sonra tekrar kullanılabilir olanlarına "ambalaj atığı" denilmektedir (Köse, 2015).

Şehirlerde oluşan ve belediyeler aracilığıyla toplanan katı atıklar Kentsel Katı Atıklar (KKA) olarak tanımlanmaktadır. Bunlar başlıca aşağıdaki bileșenleri içermektedir (Öztürk, 2015).

1. Karıșık evsel katı atıklar

2. Geri dönüştürülebilir atıklar (gazete ve mecmualar, alüminyum kutular, süt kutuları, plastik meşrubat şişeleri, metal kutular, oluklu karton vb.)

3. Evlerden çıkan tehlikeli atıklar (piller, ampuller, boya kutuları vb.)

4. Ticari ve kurumsal atıklar (iş yerleri, okullar ve diğer kamu binalarından gelen atıklar)

5. Evsel nitelikli endüstriyel katı atıklar

6. Bahçe, hal ve pazaryeri atıkları (yeşil atıklar)

7. Cadde, kaldırım ve meydan süprüntüleri

8. Hacimli atıklar (mobilya, beyaz eşya vb.)

Kentsel katı atık tanımı kapsamı dıșında kabul edilen atıklar ise aşağıdaki liste şeklinde gruplandırılmaktadır (Öztürk, 2015).

1. İnşaat, yıkıntı ve hafriyat atıkları

2. Su ve atık su arıtma tesisi çamurları

3. Atık elektrikli ve elektronik aletler

4. Hurda araçlar, lastikler ve özel işlem gerektiren diğer hacimli atıklar

5. Hastane atıkları (ameliyathane atıkları)

Şehirlerde oluşan bu kentsel katı atıklardan geri dönüştürülebilir maddelerin geri kazanımı için üç ana yöntem kullanılmaktadır (Bozdoğan, 2016). Bunlar sırasıyla şöyledir;

1. Kaynağında ayrılmış geri dönüştürülebilir maddelerin toplanmass: $\mathrm{Bu}$ yöntemde geri dönüştürülebilen maddeler atık kaynağında ayrı ayrı toplanarak toplama merkezlerine götürüldükten sonra alıcının talebine göre ek işlemlerden geçirilerek veya doğrudan pazarlanırlar.

2. Geri dönüştürülebilir maddelerin karışık toplanması: Burada katı atığın oluşum safhasında geri dönüștürülebilen ve dönüştürülemeyen olmak üzere iki gruba ayrılması gerekmektedir. Toplanan karışık geri dönüştürülebilir maddeler, Maddesel Geri Kazanım Tesisleri (MGT)'nde bileşenlerine ayrıldıktan sonra pazarlanırlar.

3. Karışı KKA'ların toplanması: $\mathrm{Bu}$ yöntemde ise toplanan atıklar doğrudan merkezi işleme tesislerine getirilirler. Burada geri dönüştürülebilir atıkların geri kazanımı için donanımlı ekipmanlar ile ayırma işlemi yapılır. $\mathrm{Bu}$ sistemler genelde ön ayırma veya atık kaynaklı yakıt üretimi amaçlı kullanılırlar.

$\mathrm{Bu}$ üç yöntem birbirleriyle karşılaştırıldığında kaynağında ayırma yönteminde atık üreticisinin önemli bir katkısı gerekmektedir. Geri dönüştürülebilir maddelerin karışık toplanmasında ise bu katkı daha az olmaktadır. Karışık toplama yönteminde ise hemen hemen hiç katkı gerekmemektedir. Toplama ve sonrasındaki atıklar işlenmesi açısından incelendiğinde, kaynağında ayrı toplamada, toplama maliyeti yüksek fakat atık işleme maliyeti düșüktür. Geri dönüștürülebilir maddelerin karışık toplanmasında bu maliyetler orta seviyede iken karışık toplama yönteminde toplama maliyeti düşük ancak atık işleme maliyeti oldukça yüksektir (Demirarslan, 2016; Gündüzalp, 2016; Yılmaz, 2010).

Gün geçtikçe hızlanan nüfus artışı ve değișen yaşam standartları gerek oluşan atık hacmini gerekse de atık kompozisyonunu çeşitlendirerek kontrol ve yönetimini zorlaştırmaktadır. Katı atıkların oluşturduğu kirlilik ile buna bağlı mevcut ve potansiyel risklerinin boyutu da her geçen gün artmaktadır. Doğal kaynakların azalması ve ekonomik nedenlerden dolayı günümüzde katı atık yönetimi her geçen gün önem kazanmaktadır. Atık olușumundan nihai bertarafa kadar olan bütün kademeler için tüm katı atık yönetiminin unsurları ve bunların birbirleri ile ilişkileri iyi bilinmesi gerekmektedir (Şekil 1) (Bozdoğan, 2016; Solak, 2018).

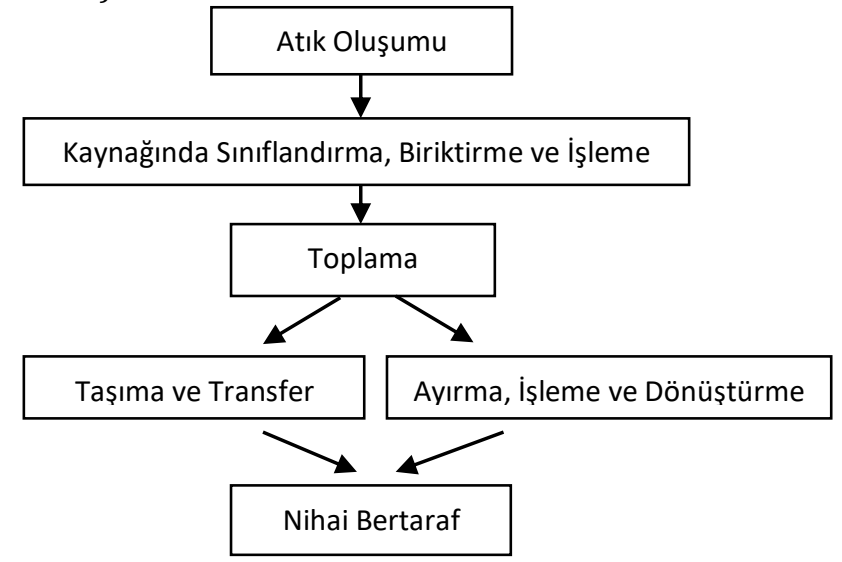

Şekil 1. Katı atık yönetim sistemi (Bozdoğan, 2016). 
Türkiye'nin birçok bölgesinde olduğu gibi 1980 yılından beri hayvancilık ve tarıma dayalı bir ekonomiye sahip olan Kahramanmaraş ili hızlı bir şekilde sanayileșme sürecine girmiștir. Tekstil bașta olmak üzere, bakırcılık, pamuk işleme (çırçır), çelik mutfak eşyası, inşaat, yem, ambalaj, gıda, kâğıt ve makine imalatı ile ısıtma ve soğutma sistemleri gibi birçok sektör ildeki sanayileşmenin öncüsü olmuştur. İlin sanayi sektöründeki tesislerine baktığımızda tekstil, metal sanayi ve gida tesislerinin ön planda olduğu görülmektedir (URL 1, 2017).

Çalışmanın yapıldı̆̆ı Dulkadiroğlu ilçesinin nüfusu Türkiye İstatistik Kurumu (TÜIK) verilerine göre 2013 yllında 216.701 kişidir. Bu sayının 110.718'i erkek, 105.983'ü kadın nüfusudur (URL 2, 2017). Son nüfus sayımından sonra Dulkadiroğlu ilçe belediyesinin yaptığı çalışmalara göre bu nüfus her geçen gün artmaktadır (Tablo 1).

Tablo 1. Ylllara göre Dulkadiroğlu ilçesinin nüfusu (URL 3, 2017)

\begin{tabular}{cccc}
\hline Yıl & $\begin{array}{c}\text { Dulkadiroğlu } \\
\text { Nüfusu }\end{array}$ & $\begin{array}{c}\text { Erkek } \\
\text { Nüfusu }\end{array}$ & Kadın Nüfusu \\
\hline 2013 & 216.701 & 110.718 & 105.983 \\
2014 & 218.029 & 111.641 & 106.388 \\
2015 & 218.067 & 111.631 & 106.436 \\
2016 & 219.548 & 112.581 & 106.967 \\
\hline
\end{tabular}

$\mathrm{Bu}$ çalışmada, Dulkadiroğlu ilçesinin belirlenen bölgelerinde oluşan ve belediye tarafından toplanan evsel katı atıkların içeriğindeki mutfak atı̆̆ı, cam, plastik, kâğıt, metal vb. atıkların miktar ve oranlarının belirlenmesi doğrultusunda bilimsel veri oluşturulması için araştırma yapılmıștır.

\section{Materyal ve Yöntem}

Bu çalışmada Kahramanmaraş ili Dulkadiroğlu ilçesi sınırları içerisinde yüksek katlı binaların yanında iş merkezlerinin ve bürolarının da yoğunlukta olduğu, nüfus yoğunluğu fazla olan "Kent Merkezi", kent merkezine yakın yüksek katlı apartmanlardan ve sitelerden oluşan yüksek gelir seviyeli nüfustan oluşan "Yüksek Gelir Seviyesi", daha çok üç veya dört katlı bahçeli evlerden ve orta gelir seviyeli nüfustan oluşan "Orta Gelir Seviyesi" ve tek veya çift katlı evler ve düşük gelir seviyeli nüfustan oluşan "Düşük Gelir Seviyesi" olmak üzere 4 bölge olarak belirlenmiștir. Bu bölgelerde ilçenin tamamını temsil edecek şekilde, Dulkadiroğlu İlçe Belediyesine ait her bölgeden 800 litrelik 4 adet çöp toplama konteynerleri belirlenmiștir (Șekil 2). Konteynerlerden alınan bu atıklar 1000 litrelik sabit hacim kaplarına alınmış ve bileşenleri tespit edilmek üzere ayrıştırma işlemine tabi tutulmuştur.

Kentsel Katı Atık (KKA)'ların karakterizasyona başlamadan önce, ayırma işlemini yapacak ekibe eğitim verilerek, tehlikeli durumlar ve prosedürler gözden geçirilmiştir. Cam parçaları, çivi, şırınga gibi kesici maddeler atık yığını içerisinde bulunabileceği göz önünde bulundurulmuş ve bunlara karşı personel uyarılmıștır. Yaralanmalara karșı riski en aza indirmek için maske, eldiven ve çizme kullanılmıştır. İçerisinde sıvı olan kaplar ve tehlikeli atık sınıfına giren diğer atıklar, ayrı bir yerde toplanarak kontrol altına alınmış, katı atık karakterizasyonu için alınan numuneler atık toplama araçlarında sıkıștırılmadan toplama merkezine getirilmiștir (Șekil 3a). Bu işlemler Pazartesi ve Cuma günleri olmak üzere haftanın iki günü gerçekleștirilmiş olup pazartesi günü ile hafta sonu, Cuma günü ile de hafta içini temsil edecek numuneler elde edilmiştir.

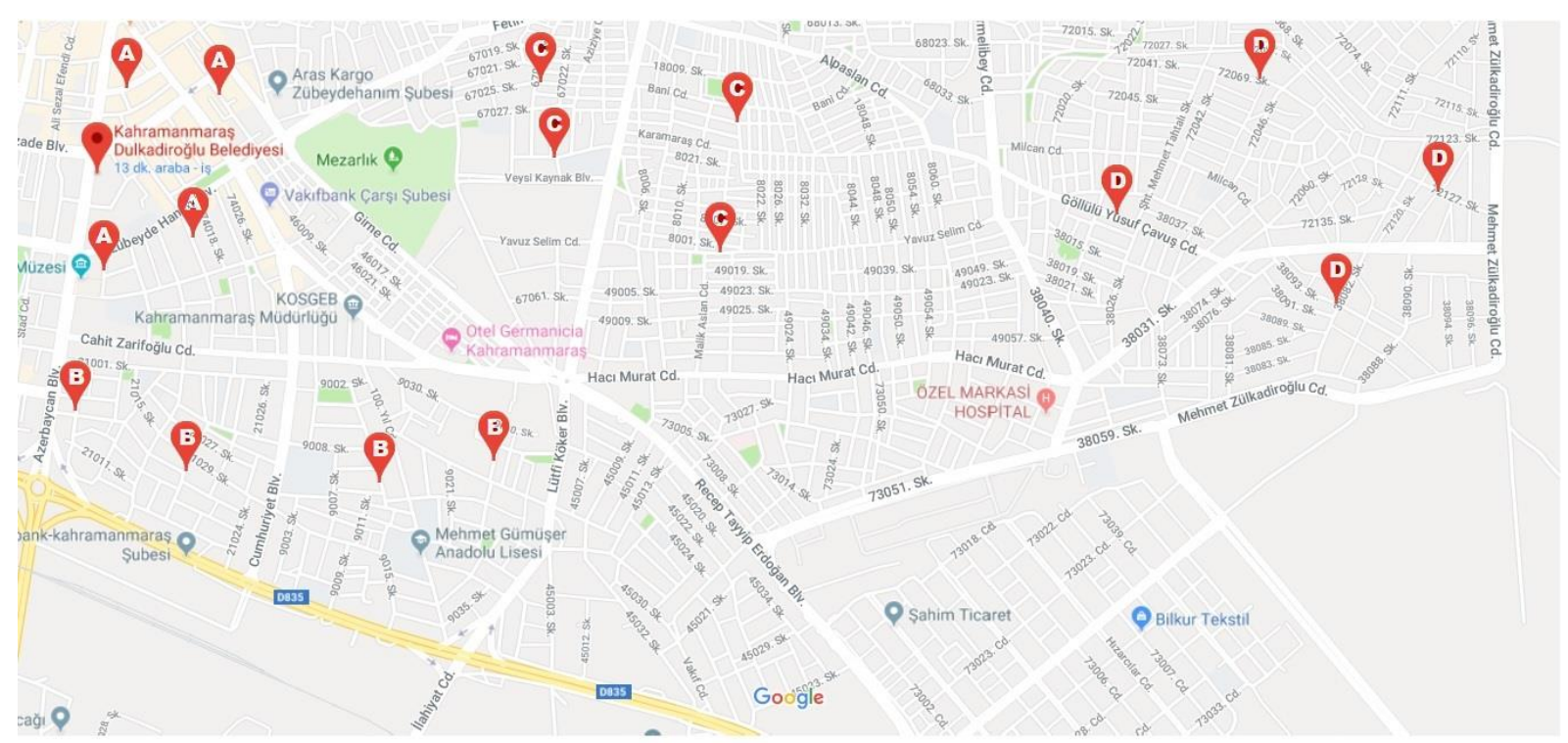

Şekil 2. Dulkadiroğlu belediyesi sınırları içerisinde yerleri belirlenen çöp konteynerlerinin konumları: Kent Merkezi (A), Yüksek Gelir Seviyesi (B), Orta Gelir Seviyesi (C), Düşük Gelir Seviyesi (D) 

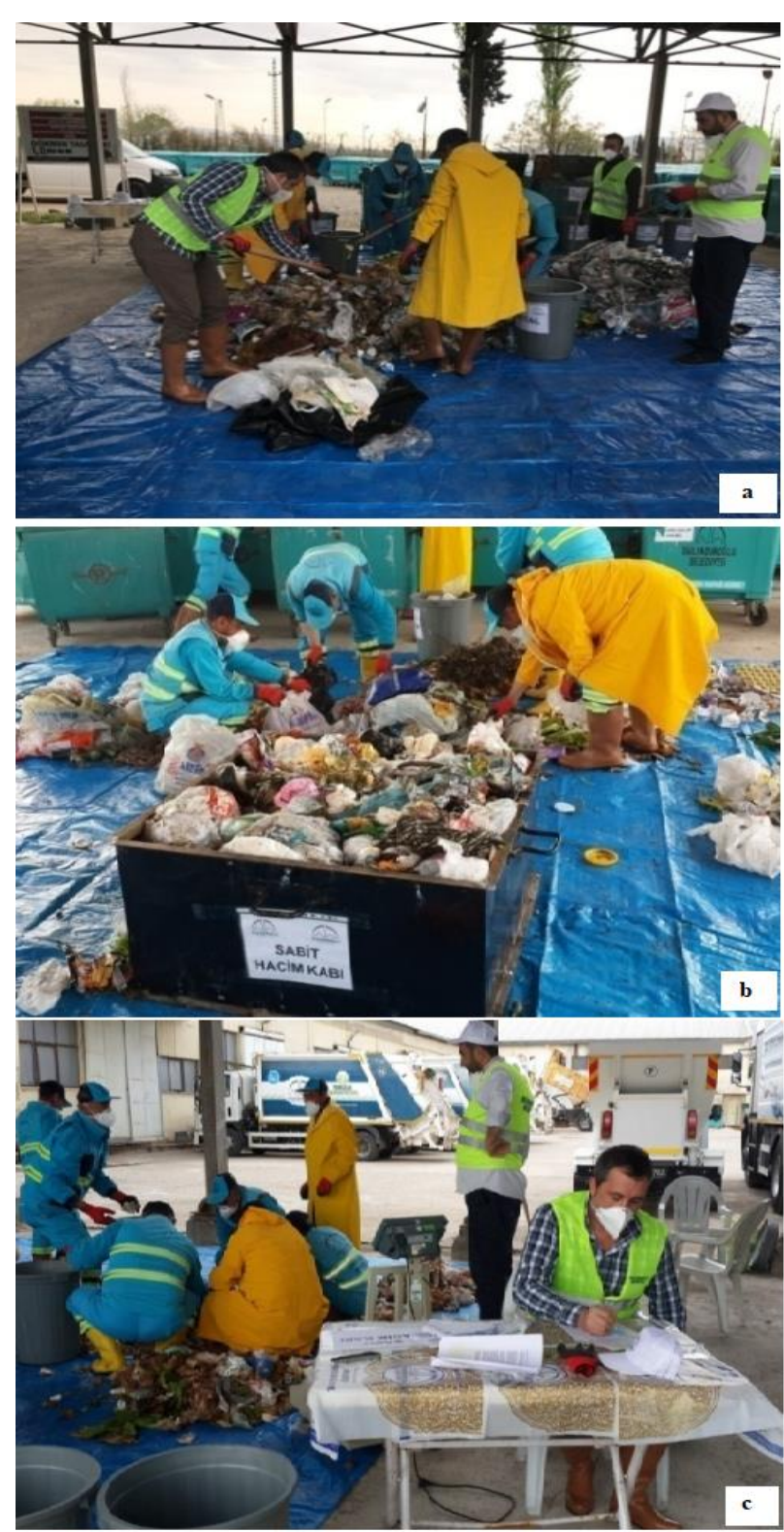

Şekil 3. Karakterizasyon çalışması (a), Dolu sabit hacim kabı (b), Tartım sonuçlarının kaydedilmesi (c)

KKA'ların ayrıştırılması için düz bir zemine $7 \mathrm{~m}$ x $7 \mathrm{~m}$ boyutlarında plastik örtü serilmiș ve tartım yapacak kantar söz konusu zeminin üzerine yerleştirilmiştir. Farklı bölgelerden gelen atıkların bulunduğu çöp konteynerleri ayrı yerlere konularak üzerlerine atıkların geldiği bölgeler not edilmiştir. Yığın halindeki atıklardan her bölgeden eșit miktarda olacak şekilde alınmış ve $1 \mathrm{~m} \quad \mathrm{x} \quad 1 \mathrm{~m} \quad \mathrm{x} \quad 0,5 \mathrm{~m}$ ölçülerindeki altı ve üstü açık, kulplu sabit hacim kabının içi tamamen dolduracak şekilde konulmuştur (Şekil 3b). Her atık grubu için sabit hacim kabı 2 defa bu şekilde doldurulmuş ve böylece her gruptan 1'er metreküp temsil edici numune alınmıştır. Aynı uygulamalar diğer bölgeler için de tekrarlanmıştır.

Atıklarla doldurulan sabit hacim kabı kaldırılarak plastik örtü üzerinde kalan atıklar ve yemek artıkları en sona bırakılacak şekilde Tablo 3'de belirlenen katı atık bileșen gruplarına göre ayrıștırılmıștır. Ayıklama sırasında bağlanmış poşetler varsa bunların içleri açllarak uygun kaplara konulmuştur.

Tablo 3. Katı atık bileșenleri (Yenice, 2009)

\begin{tabular}{ll}
\hline Katı Atık Bileşen Grupları & Katı Atık Bileşenleri \\
\hline Mutfak Atıkları & Yemek artıkları, ekmek, sebze, meyve \\
Kâğıt & Gazete, dergi, defter \\
Karton & Süt kutusu, meyve suyu kutusu, tetrapak \\
Hacimli karton & Karton kutular \\
Plastik & Tüm plastikler \\
Cam & Cam şişe, cam bardak, kavanoz \\
Metal & Teneke kutu, çatal, bıçak \\
Hacimli metal & Metal dolap, masa vs. \\
Atık elektrik ve elektronik & Telefon, radyo vs. \\
ekipman & Pil, boya kutusu, deterjan kutusu, ilaç \\
Tehlikeli atık & kutuları \\
Park ve bahçe atıkları & Dal, ağaç parçası, çim vs. \\
Diğer yanmayanlar & Taş, kum, toz, seramik \\
Diğer yanabilenler & Kumaş, çocuk bezi, ayakkabı, terlik, yastık, \\
Diğer yanabilir hacimli atıklar & halı, kilim, çanta \\
Diğer yanmayan hacimli atıklar & Mobilya, tahtadan yapılmış malzemeler vs. \\
Diğer (yukarıdaki gruplar hariç) & - \\
\hline
\end{tabular}

Ayrıștırılan bileșenler, üzerinde madde gruplarının isimlerinin yazılı olduğu plastik kovalara konulmuştur. Sabit hacim kabıyla alınan numunenin tamamı uygun kaplara dağıtıldıktan sonra tartım ișlemine geçilmiștir. Her kap ayrı ayrı tartılmıș ve daha sonra aynı grupta yer alan aynı tür bileşenlerin miktarları toplanarak, elde edilen tartım sonuçları yüzde $\mathrm{kg}$ oranları hesaplanmıștır (Şekil 3c).

\section{Bulgular ve Tartışma}

Bu çalışmada 2017 yılı Nisan-Mayıs aylarında Kahramanmaraş ili Dulkadiroğlu ilçesi sınırları içerisinde "Kent Merkezi", "Düşük Gelir Seviyesi", "Orta Gelir Seviyesi" ve "Yüksek Gelir Seviyesi"nden oluşmak üzere 4 bölge belirlenerek, bu bölgelerde bulunan belediyeye ait çöp toplama konteynerlerinden alınan evsel katı atıklar ayrıştırılarak atık bileșenleri belirlenmiș ve elde edilen veriler incelenmiştir.

Kent merkezinden alınan ve bileșenleri belirlenen evsel katı atıklar için çıkan sonuçlara bakıldığında, en yüksek oranı \% 48,70 ile mutfak atıklarının olușturduğu, ikinci sırada \% 19,10 oranla kâğıt atıkların olușturduğu görülmektedir. Plastik ve cam atıkların ise $\% 14,80$ ve $\% 11,50$ ile üçüncü ve dördüncü yüksek bileșenler olduğu görülmektedir (Şekil 4).

Gelir seviyesi düșük olarak belirlenen bölgeden alınan ve bileșenleri belirlenen evsel katı atıklar için çıkan sonuçlarına göre en yüksek oranı \% 58,50 oranla mutfak atıklarının oluşturmaktadır. Plastik, diğer yanmayanlar ve diğer yanabilir hacimli atıkların oranının ise \% 10 dolaylarında olup, birbirine yakın değerlerde olduğu görülmektedir (Şekil 5). 


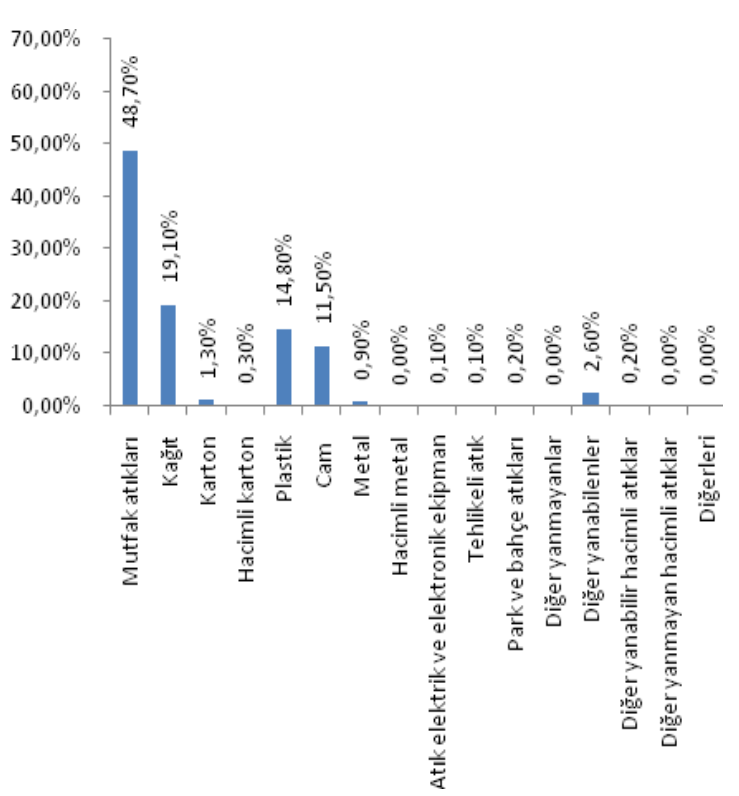

Şekil 4. Kent merkezi için evsel katı atık bileşenleri $\%$ kg miktarları

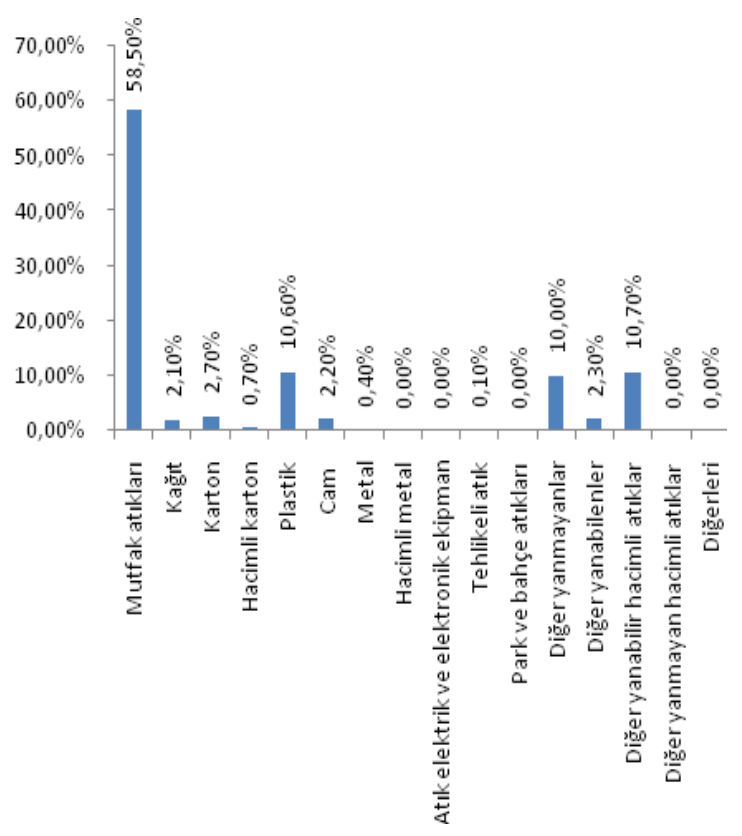

Şekil 5. Düşük gelir seviyesi için evsel katı atık bileşenleri \% kg miktarları

Gelir seviyesi orta olarak belirlenen bölgeden alınan ve bileșenleri belirlenen evsel katı atıklar için çıkan sonuçlarda mutfak atıkları en yüksek orana \% 53,70 sahipken, ikincisi \% 20 oran ile diğer yanabilir atıklar, üçüncüsü ise \% 14 oran ile plastik atıkların oluşturduğu görülmektedir (Şekil 6).

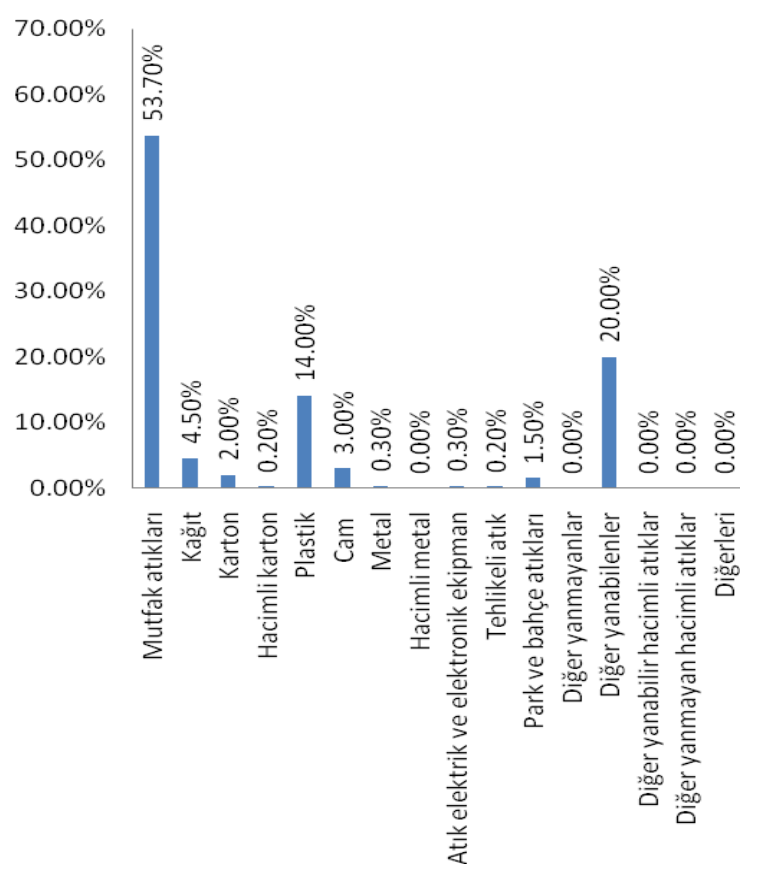

Şekil 6. Orta gelir seviyesi için evsel katı atık bileşenleri \% kg miktarları

Gelir seviyesi yüksek olarak belirlenen bölgeden alınan ve bileșenleri belirlenen evsel katı atıklar için çıkan sonuçlara göre en yüksek oran $\% 62,70$ ile yine mutfak atıklarının, ikincisi \% 14,30 oran ile diğer yanabilir atıkların, üçüncüsü ise $\% 10,40$ oran ile plastik atıkların oluşturduğu görülmektedir (Şekil 7).

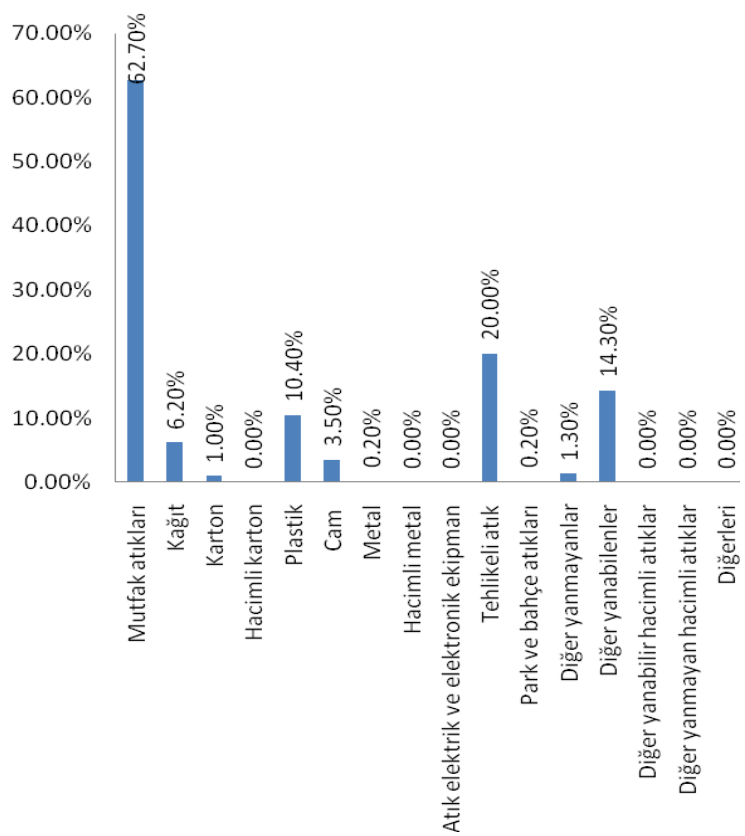

Şekil 7. Yüksek gelir seviyesi için evsel katı atık bileşenleri \% kg miktarları 


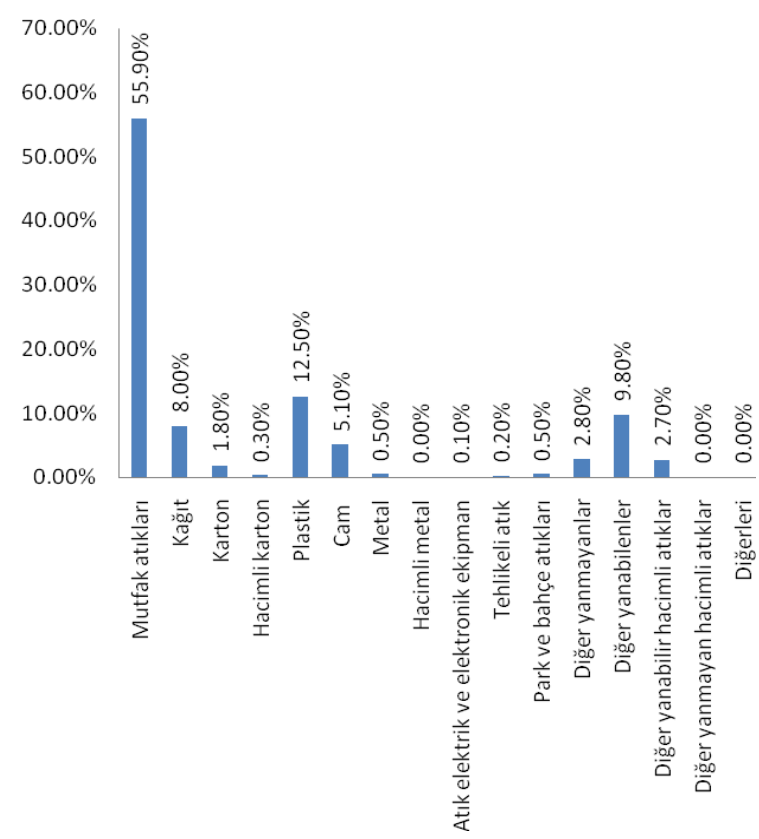

Şekil 8. Katı atık bileşenleri genel toplam \% kg miktarları

Genel olarak bütün bölgelerin atık bileşenleri için çıkan sonuçlara göre en yüksek oranı $\% 55,90$ ile mutfak atıklarının, sonra sırasıyla \% 12,50 ile plastik atıkların, \% 9,80 ile diğer yanabilen atıkların ve $\% 8$ ile kâğıt atıklarının olușturduğu görülmektedir (Șekil 8). Kâğıt, cam ve plastik gibi geri dönüștürülebilir atıklar bakımından sonuçlar incelendiğinde bu atıkların en yüksek oranını kent merkezinden gelen atıkların oluşturduğu görülmektedir. Gelir seviyesi orta olarak belirlenen bölge ile gelir seviyesi yüksek olarak belirlenen bölgelerin sonuçlarına bakıldığında, birbirine yakınlık olduğu dikkat çekmektedir.

\section{Sonuç ve Öneriler}

Atık oluşumunu ve bileşenlerini etkileyen en önemli faktörler; yerleşim yerinin enerji kaynakları, mevsimsel değişimler, sosyo-ekonomik yapı ve kişi başına düşen gelir seviyesi olarak değişmektedir. Çalışmanın sonuçlarına bakıldığında en yüksek bileșenin mutfak atıklarının yani organik atıkların oluşturduğu görülmektedir. Bu nedenle bu atıkların ülke ekonomisine kazandırılması büyük önem taşımaktadır. Mutfak atıklarından sonra en önemli bileșeni kâğıt, plastik, cam ve metal gibi geri dönüştürülebilir atıklar oluşturmaktadır. Kâğıt, cam ve plastik gibi geri dönüştürülebilir atıklar bakımından sonuçlar incelendiğinde bu atıkların en yüksek oranda kent merkezlerinden kaynaklandığ görülmektedir. Çöp kamyonları ile toplanan kentsel atıklar "Katı Atık Depolama Sahası"nda depolanmaktadır. Bununla birlikte, Dulkadiroğlu ilçe belediyesi adına yetkili ve lisanslı bir geri dönüşüm firması ilçe genelinde kaynağında sadece ambalaj atı̆̆ı toplamaktadır. Söz konusu şirketin kaynağında ayrı olarak topladığı ambalaj atığı miktarı ise aylık olarak 35 ton civarındadır (URL 3, 2017).

Sanayileşmiş ülkelere bakıldığında kentsel atıkların organik kısımlarının en verimli olabilecek şekilde enerji üretiminde kullanıldığı görülmektedir. İyi bir katı atık yönetim modelinin temel fonksiyonu, katı atığı bertaraf ederek boş bir alana atmak değil, onu ekonomik bir değer olarak görüp, çevreye en uyumlu yöntemlerle ekonomiye yeniden kazandırmak olacaktır (Lüy, 2007).

Kentsel katı atıklardan enerji elde etmek sadece bir yenilenebilir enerji uygulaması olmayı, aynı zamanda metan ve karbondioksit emisyonlarını azaltarak çevre korunmasına hizmet etmektedir. Kentsel atıklardan sağlanan enerji bölgesel enerji ihtiyacını da karşılayarak doğalgaz ve petrol gibi dövizle ithal edilen enerji kaynaklarına olan bağımlılığı da azaltmaktadır.

\section{Teşekkür}

Bu çalışma, Kahramanmaraş-Dulkadiroğlu Belediyesi Çevre Koruma ve Kontrol Müdürlüğü tarafından desteklenmiştir.

\section{Conflict of Interest / Çıkar Çatışması}

Yazarlar tarafından herhangi bir çıkar çatışması beyan edilmemiştir.

No conflict of interest was declared by the authors.

\section{Kaynaklar}

Bozdoğan N.D. 2016. Kahramanmaraş Ambalaj Atıklarının Toplanması, Ayrıştııılması ve Geri Dönüşümlerinin Araştırılması, Kahramanmaraș Sütçü İmam Üniversitesi Fen bilimleri Enstitüsü Çevre Mühendisliği Bölümü, Yüksek Lisans Tezi, $57 \mathrm{~s}$, K.Maraş

Bozdoğan N.D., Ziba C.A., Dolaz M. 2016. Kahramanmaraş Merkez İlçesi ve Bazı Mahallelerindeki Cam, Plastik ve Kağıt Atık Potansiyelinin Belirlenmesi, KSU Mühendislik Bilimleri Dergisi, s 19(3).

Demirarslan K.O., Demirarslan D. 2016. Kentlerde Yeni Yerleşim Alanlarının Gelişimi ve Katı Atık Sorunu: İzmit-Yahya kaptan Mahallesi Örneği, Artvin Çoruh Üniversitesi Doğal Afetler Uygulama ve Araştırma Merkezi Doğal Afetler ve Çevre Dergisi, Cilt:2, Sayı:2, s 108-120.

Gündüzalp A. A., Güven S, 2016. Atık, Çeşitleri, Atık Yönetimi, Geri Dönüşüm ve Tüketici: Çankaya Belediyesi ve Semt Tüketicileri Örneği, Hacettepe Üniversitesi Sosyolojik Araşmalar Dergisi, ISSN 1304-2823, s 1-19. 
Köse N., Sun D., Tulum M., Türegün A. Y., Yamaner C., Kırca Ö., Süral H. 2015. Geri Dönüştürülebilir Ambalaj Atıkları Yönetim Sistemi Tasarımı, Endüstri Mühendisliği Dergisi, Cilt: 26, Sayı: 2, s 35-51.

Lüy E., Varınca K.B., Kemirtlek A. 2007. Katı Atık Geri Kazanım Çalışmaları; İstanbul Örneği, TÜRKAY 2007, AB Sürecinde Türkiye'de Katı Atık Yönetimi ve Çevre Sorunları Sempozyumu

Öztürk İ. K. 2011. Ambalaj Atığı Yönetimde Bazı Ülke Uygulamaları, Ambalaj Geri Kazanım Çevre Dergisi, Mart-Nisan-Mayıs Sayısı, s 44.

Öztürk, İ., Arıkan, O., Altınbaș, M., Alp, K., Güven, H. 2015. Katı Atık Geri Dönüşüm ve Arıtma Teknolojileri, ISBN: 978-605-9186-00-1.

Solak S. G., Pekküçükşen Ş. 2018. Türkiye'de Kentsel Katı Atık Yönetimi: Karşılaştırmalı Bir Analiz, MANAS Sosyal Araştırmalar Dergisi, Cilt: 7, Sayı: 3, s 653-683.

T.C. Resmi Gazete 2015. Ambalaj Atığı Kontrolü Yönetmeliği, 2 Nisan, Sayı: 29314.

URL 1: Kahramanmaraş Büyükşehir Belediyesi 2014. 2015-2019 Stratejik Planı, Eylül, 20-24, www.kahramanmaras.bel.tr (Erişim tarihi: 10 Kasim 2017)

URL 2: Türkiye İstatistik Kurumu 2013. www.tüik.gov.tr (Erişim tarihi: 10 Kasım 2017)

URL 3: Dulkadiroğlu Belediyesi 2016. www.dulkadiroglu.bel.tr (Erişim tarihi: 10 Kasım 2017)

Yenice M.K., Doğruparmak Ş.Ç., Durmuşoğlu E. 2009. Kocaeli İli Katı Atık Karakterizasyonu, TÜRKAY 2009 Türkiye'de Katı Atık Yönetimi Sempozyumu, Yıldız Teknik Üniversitesi, 15-17 Haziran, İstanbul.

Yılmaz A., Bozkurt Y. 2010. Türkiye'de Kentsel Katı Atık Yönetimi Uygulamaları ve Kütahya Katı Atık Birliği (Kükab) Örnegi, Süleyman Demirel Üniversitesi, İktisadi ve İdari Bilimler Fakültesi Dergisi, Cilt: 15, Sayı:1, s 11-28. 